\title{
Cytotoxicity of Cratoxylum Formosum Subsp. Pruniflorum Gogel Extracts in Oral Cancer Cell Lines
}

\author{
Bundit Promraksa ${ }^{1}$, Jureerut Daduang ${ }^{2,3}$, Ponlatham Chaiyarit ${ }^{4,5}$, Ratree \\ Tavichakorntrakool $^{3,6}$, Tueanjit Khampitak ${ }^{1}$, Narintorn Rattanata ${ }^{7}$, Roongpet \\ Tangrassameeprasert ${ }^{1}$, Patcharee Boonsiri ${ }^{1 *}$
}

\begin{abstract}
Background: Oral cancer is a health problem in Thailand. Cratoxylum formosum subsp. pruniflorum Gogel (Teawdang), normally consumed in northeast Thailand, has proven cytotoxic to cervical cancer cell lines including HeLa, SiHa and C-33A. Recently, Asian oral cancer cell lines, ORL-48 and ORL-136, were established. Therefore, we aimed to study cytotoxicity of Teawdang in these. Total phenolic (TPC) and flavonoid content (TFC), and antioxidant activity of Teawdang were also determined. Materials and Methods: Teawdang was purchased from Khon Kaen market during June-October 2013. Hexane (CHE), ethyl acetate (CEE) and methanol (CME) extracts of its edible part were analyzed for TPC by the folin-ciocalteau method and for TFC by an aluminium colorimetric method. Antioxidant activity and cytotoxicity in normal Vero cells and oral cancer cells were investigated. Cell viability was assessed using 3-(4,5-dimethylthiazol-2yl)-2,5-diphenyltetrazolium bromide (MTT) assays. Results: CME and CEE had higher TPC and TFC and antioxidant activity than CHE. Both CME and CEE, at $200 \mu \mathrm{g} d r y \mathrm{wt} / \mathrm{mL}$, were cytotoxic to the studied oral cancer cell lines. However, CME was cytotoxic to Vero cells whereas CEE was not. Compared to Vero cells, CEE significantly inhibited ORL-48 and ORL-136 growth ( $p=0.03$ and $p=0.02$, respectively). Conclusions: CEE exhibited cytotoxic effects on the studied oral cancer cell lines but not normal Vero cells. The bioactive compounds in CEE should be further purified and elucidated for their mechanisms of action for development as anticancer agents.
\end{abstract}

Keywords: Antioxidant - cytotoxicity - Cratoxylum formosum subsp. pruniflorum Gogel - oral cancer cell line

Asian Pac J Cancer Prev, 16 (16), 7155-7159

\section{Introduction}

Oral cancer becomes a health problem worldwide because of the increasing patient number each year. In 2012, there were about 67,000 new cases in Southeast Asian countries (Ferlay et al., 2013). In northeast Thailand, the incidence of oral cancer is the highest in country (Khuhaprema et al., 2010) and its incidence rates are increasing in female (Vatanasapt et al., 2011). The risk factors are tobacco smoking, alcohol drinking (Sturgis et al., 2004) and oral human papilloma virus (HPV) infection (Gillison et al., 2008). Oral sex behavior might cause HPV transmission (Heck et al., 2010). Oral carcinogenesis occurs from the imbalance between antioxidant and free radicals caused by oxidative stress (Patel et al., 2008). The molecular mechanisms of anticancer agents are induction of apoptosis and suppression of cancer cell cycle (Surh, 2003). A previous study reported side effects of several anticancer drugs, including neurotoxicity and electrolyte disturbance (Dzagnidze et al., 2007). Moreover, multidrug resistance has been reported in oral cancer patients through the overexpression of drug efflux transporters induced from radiotherapy at plasma membrane ( $\mathrm{Ng}$ et al., 1998; Perez-Sayans et al., 2010). At present, natural products have been focus as a potential source of anticancer agents.

Epidemiological studies reveal that daily consumption of vegetables can reduce cancer (Chen et al., 2014; Wang et al., 2014). The extracts of some Thai vegetables could effectively induce apoptosis in oral cancer (Manosroi et al., 2015) and cervical cancer cells (Palasap et al., 2014). Recently, Cratoxylum formosum subsp. pruniflorum Gogel., which its Thai name is Teawdang, has become an attractive functional food due to its phytochemical composition (Nonpunya et al., 2014). It is consumed in northeast Thailand as side dishes to relieve fever and stomach ache. In south and southwest China, it is used as ordinary tea (Xiong et al., 2014). The ethanolic extract of Teawdang leave contained toxyloxanthone $\mathrm{B}$ and

${ }^{1}$ Department of Biochemistry, Faculty of Medicine, ${ }^{2}$ Department of Clinical Chemistry, ${ }^{3}$ Centre for Research and Development of Medical Diagnostic Laboratories, ${ }^{6}$ Department of Clinical Microbiology, Faculty of Associated Medical Sciences, ${ }^{4}$ Department of Oral Diagnosis, ${ }^{5}$ Research Group of Chronic Inflammatory Oral Disease and Systemic Disease Associated with Oral Health, Faculty of Dentistry, ${ }^{7}$ Department of Biochemistry, Faculty of Science, Khon Kaen University, Khon Kaen, Thailand *For correspondence: patcha_b@kku.ac.th 
vismione $\mathrm{D}$ which have anti-neuroinflammatory activity (Xiong et al., 2014). Teaw contained chlorogenic acid (Maisuthisakul et al., 2006) which had high antioxidant activity and high cytotoxic effect to oral squamous cell carcinoma (HSC-2 cell line) (Jiang et al., 2000). Teawdang also had in vitro cytotoxicity on liver cancer cell lines (HepG2) by effectively reducing hepatitis B virus (Waiyaput et al., 2012; Nonpunya et al., 2014). Recently, the Asian oral cancer cell lines, ORL-48 and ORL-136, were established as in vitro model for studying a disease prevalent in Asia (Hamid et al., 2007). We hypothesized that Teawdang may be cytotoxic to these oral cancer cell lines. Therefore, we aim to investigate cytotoxic effect of Teawdang extracts on these oral cancer cell lines. The phenolic content and antioxidant activity were also determined.

\section{Materials and Methods}

\section{Chemicals and reagents}

The organic solvents including hexane, ethyl acetate, and methanol were purchased from S.C. Science (Thailand). Phosphoric acid and hydrochloric acid $(\mathrm{HCl})$ were obtained from RCI labscan (Thailand). Dimethyl sulfoxide (DMSO) was supplied from Amresco Inc. (USA). 2,4,6-tripyridyl-s-triazine (TPTZ), 2,2-diphenyl-1picrylhydrazyl (DPPH) and hydrocortisone solution were obtained from Sigma-Aldrich (Missouri, USA). Iron (III) chloride hexahydrate $\left(\mathrm{FeCl}_{3} \cdot 6 \mathrm{H}_{2} \mathrm{O}\right)$ was purchased from AnalaR (England). Dulbecco's Modified Eagle Medium (DMEM), Ham F'12 and bovine serum albumin (BSA) were obtained from Gibco BRL (New York, USA).

Preparation of Teawdang

Teawdang was purchased from local markets in Khon Kaen province, Thailand during June to October 2013. Its edible part was cleaned with distilled water and dried in a hot air oven at $50^{\circ} \mathrm{C}$ till its dried. The dried Teawdang was ground to fine powder.

\section{Extraction of Teawdang}

Teawdang powder was macerated in 1 liter of hexane for 5 days. After filtration through Whatman No. 1 filter paper, the residue was re-extracted by the same procedure with ethyl acetate and methanol respectively. The organic solvents were removed by using a rotary evaporator (Buchi, Japan). Then, crude hexane, ethyl acetate, and methanol extracts (CHE, CEE and CME respectively) were kept at $4^{\circ} \mathrm{C}$ for further analysis.

\section{Determination of total phenolic content (TPC)}

Total phenolic content of crude extracts were determined according to a modified method of Daduang et al (2011). All crude extracts were dissolved in 5\%DMSO and final concentration was adjusted to $1 \mathrm{mg} / \mathrm{mL}$. One hundred microliters of the crude extract was mixed with $500 \mu$ L of $0.2 \mathrm{~N}$ Folin-Ciocalteau reagent and incubated in the dark for $30 \mathrm{~min}$. Then $400 \mu \mathrm{L}$ of $7 \% \mathrm{Na}_{2} \mathrm{SO}_{4}$ was added. After standing in the dark for $5 \mathrm{~min}$, the absorbance at 750 $\mathrm{nm}$ was recorded by using a spectrometer (Genesys 20, Thermo scientific, USA). Gallic acid, at a concentration range $10-100 \mu \mathrm{g} / \mathrm{mL}$, was used for preparation of a calibration curve. The concentration of total phenolic was expressed as milligram of gallic acid equivalent per gram dry weight (mg GAE/g dry wt.). The experiment was carried out in triplicate.

\section{Determination of total flavonoid content (TFC)}

The determination of total flavonoid content of crude extracts was performed by using a modified method of Patel et al (2010). Two hundred and fifty microliters of crude extracts were mixed with $75 \mu \mathrm{L}$ of $5 \% \mathrm{NaNO}_{2}$. After standing for $5 \mathrm{~min}, 150 \mu \mathrm{L}$ of $10 \% \mathrm{AlCl}_{3} \cdot 6 \mathrm{H}_{2} \mathrm{O}$ was added into the mixture and left for another $6 \mathrm{~min}$. Five hundred $\mu \mathrm{L}$ of $1 \mathrm{M} \mathrm{NaOH}$ was added and total volume was adjusted to $2 \mathrm{~mL}$ with distilled water and incubated at room temperature for $30 \mathrm{~min}$. The absorbance at $415 \mathrm{~nm}$ was read. A blank and standard compound were distilled water and quercetin (concentration range 50-800 $\mu \mathrm{g}$ / $\mathrm{mL}$ ) respectively. Total flavonoid content was reported as milligram of quercetin equivalent per $1 \mathrm{~g}$ dry weight (mg QE/g dry wt.). All measurements were carried out in triplicate.

\section{Ferric reducing antioxidant power (FRAP) assay}

The determination of total antioxidant activity by FRAP method was performed by using a modified method of Benzie and Strain (1996). FRAP reagent was freshly prepared by mixing $300 \mathrm{mM}$ acetate buffer $\mathrm{pH} 3.6,10 \mathrm{mM}$ TPTZ in $40 \mathrm{mM} \mathrm{HCl}, 20 \mathrm{mM} \mathrm{FeCl} \cdot \cdot 6 \mathrm{H}_{2} \mathrm{O}$ at a ratio of 10:1:1. One milliliter of the crude extracts was dissolved in $5 \%$ DMSO and $1 \mathrm{~mL}$ of FRAP reagent was added and left at room temperature for $5 \mathrm{~min}$. The absorbance at $593 \mathrm{~nm}$ was recorded. A calibration curve was prepared by using standard gallic acid at various concentrations (5-50 $\mu \mathrm{g}$ / $\mathrm{mL})$. This assay was performed in triplicate.

\section{2,2-Diphenyl-1-picrylhydrazyl (DPPH) radical scavenging activity assay}

DPPH radical scavenging ability was analyzed by a modified method of Clarke et al (2013). In a 96-well plate, $120 \mu \mathrm{L}$ of crude extract and $120 \mu \mathrm{L}$ of $100 \mu \mathrm{M}$ DPPH reagent were mixed in each well. The mixture was vigorously shaking for $2 \mathrm{~min}$ and left for $30 \mathrm{~min}$ at room temperature with light protection. After that the absorbance was measured at $540 \mathrm{~nm}$ by using a microplate reader (Tecan, France). All measurement was carried out in triplicate. The percentage inhibition activity was calculated as below:

\section{$\% D P P H$ inhibition $=\left[\left(A^{0}-A^{1}\right) / A^{0}\right] \times 100$}

$A^{0}=$ the absorbance of DPPH reagent with $120 \mu \mathrm{L}$ of distilled water

$A^{l}=$ the absorbance of DPPH reagent with $120 \mu \mathrm{L}$ of standard gallic acid or the extract

\section{Cell lines and culture condition}

The cell lines used in this study were Vero cells (Cercopithecus aethiops normal kidney) which obtained from Faculty of Associated Medical Scicences, Khon Kaen University and two oral cancer cell lines including ORL-48 and ORL-136 which obtained from the Cancer Research Initiatives Foundation (CARIF, Malaysia). All cell lines were cultured in the mixture of DMEM and 
Table 1. Total Phenolic Content, Total Flavonoid Content and Antioxidant Activity of Teawdang Extracts

\begin{tabular}{lcccc}
\hline Extracts & TPC & TFC & FRAP & \%DPH inhibition* \\
& $(m g$ GAE/g dry wt $)$ & $(m g$ QE/g dry wt $)$ & $($ mg GAE/g dry wt $)$ & 32.63 \\
\hline CHE & $26.16 \pm 1.55$ & $53.67 \pm 17.79$ & $8.30 \pm 1.66$ & 50.79 \\
CEE & $83.93 \pm 6.06$ & $238.67 \pm 55.64$ & $241.59 \pm 10.15$ & 60.23 \\
CME & $161.63 \pm 12.85$ & $495.00 \pm 55.49$ & $435.25 \pm 15.87$ & \\
\hline
\end{tabular}

TPC, TFC and FRAP values are expressed as mean $\pm \mathrm{SD},(\mathrm{n}=3) ; *=$ tested concentration at $1 \mathrm{mg}$ dry $\mathrm{wt} / \mathrm{mL}$

Ham F'12 at the ratio 1:1 with $10 \% \mathrm{BSA}, 1 \%$ penicillinstreptomycin and hydrocortisone solution $(1.16 \mathrm{~mL} / 40$ mL complete medium).

\section{Cytotoxicity test}

The cytotoxicity of Teawdang extracts on Vero and oral cancer cell lines were performed in a 96 well plate. One hundred microliter of resuspend cells $\left(2 \times 10^{5}\right.$ cells $\left./ \mathrm{mL}\right)$ were seeded into each well and allowed to attach the plate at $37^{\circ} \mathrm{C}$ in $5 \%$ carbondioxide atmosphere for $24 \mathrm{hrs}$. Then $100 \mu \mathrm{L}$ of each crude extract (final concentration 50-400 $\mu \mathrm{g}$ dry $\mathrm{wt} / \mathrm{mL}$ ), which were diluted with $1 \% \mathrm{DMSO}$ and filtrated with $0.22 \mu \mathrm{m}$ pore size filter (Agela Technologies, USA), was added to the cells. After that, they were incubated for $24 \mathrm{hrs}$. Cell treated with $1 \%$ DMSO was negative control.

\section{Cell viability assay}

After incubation for $24 \mathrm{hrs}$, cell viability was detected by 3-(4,5-dimethylthiazol-2yl)-2,5-diphenyltetrazolium bromide (MTT) assay (Mahavorasirikul et al., 2010). Cells were treated with $5 \mathrm{mg} / \mathrm{mL}$ MTT reagent $(50 \mu \mathrm{L} /$ well) for $4 \mathrm{hrs}$ at $37^{\circ} \mathrm{C}$ and then $200 \mu \mathrm{L}$ of $1 \mathrm{x}$ phosphate buffer saline (PBS) pH 7.4 was added to each well to dissolve the formazan crystals. The absorbance was recorded at $492 \mathrm{~nm}$ by using a microplate reader (Tecan, France). Percentage of residual cell inhibition was calculated by a formula below. Cell viability $>50 \%$ at $400 \mu \mathrm{g}$ dry wt $/ \mathrm{mL}$ was considered as non-cytotoxic.

$\%$ Cell viability $=\left[\left(A^{\text {sample }}-A^{\text {control }}\right) / A\right.$ of cell without treatment] $x 100$

$\left(A^{\text {control }}=\right.$ absorbance at $492 \mathrm{~nm}$ of well with $100 \mu \mathrm{L} 1 \%$ DMSO,

$A^{\text {sample }}=$ absorbance at $492 \mathrm{~nm}$ of well with crude extract)

\section{Statistical analysis}

The results were expressed as mean \pm standard deviation (SD). Cell viability was analyzed (one way ANOVA) by using SPSS windows version 17. Values of $\mathrm{p}<0.05$ was considered as statistically significant.

\section{Results}

Total phenolic and total flavonoid content

Total phenolic and total flavonoid content of CHE, CEE and CME are shown in Table 1. The highest content of TPC and TFC was found in CME. Among all extracts, TPC were well correlated with TFC of the extracts $(\mathrm{r}=0.99)$.

\section{Antioxidant activity of Teawdang extracts}

CME had the highest reducing power $(435.25 \pm 15.87$ mg GAE/g dry wt) follow by CEE and CHE respectively
Table 2. Cytotoxicity of Teawdang Extracts on Oral Cancer Cell Lines

\begin{tabular}{lccc}
\hline Extracts & \multicolumn{3}{c}{ IC50 value $(\mu \mathrm{g}$ dry wt $/ \mathrm{mL})$} \\
& Vero & ORL-48 & ORL-136 \\
\hline CHE & $>400$ & $>400$ & $>400$ \\
CEE & $>400$ & $290.27 \pm 13.85$ & $167.43 \pm 11.67$ \\
CME & $192.62 \pm 41.67$ & $209.20 \pm 8.14$ & $44.82 \pm 27.95$ \\
\hline
\end{tabular}

The IC50 values are shown as mean $\pm \mathrm{SD}(\mathrm{n}=3)$, IC50 $>400 \mu \mathrm{g}$ dry wt/ $\mathrm{mL}$ was non cytotoxic

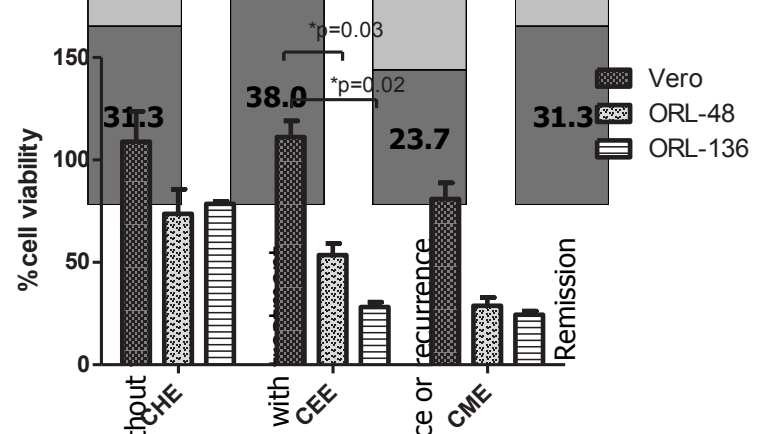

Figure 1. Cell Viability of Vero, ORL-48 and ORL136 after Treated with Teawdang Extracts $(200 \mu \mathrm{g}$ dry $w t / m L)$

(Table 1). At the same concentration (1 mg dry $\mathrm{wt} / \mathrm{mL}$ ), CME showed higher \%DPPH inhibition than CEE and CHE. In addition, DPPH radical scavenging activity of CME was higher than $1 \mathrm{mg} / \mathrm{mL}$ gallic acid (60.23 vs $57.49 \%)$. There was a relationship between DPPH radical scavenging activity and ferric reducing power $(r=0.98)$.

Cytotoxic effect of Teawdang extracts on Vero and oral cancer cell lines

In Table 2, CME and CEE could inhibit ORL-48 and ORL-148 cells whereas CHE was non-cytotoxic to all tested cell lines. Although CEE had higher IC50 than CME for both oral cancer cell lines, it was not toxic to Vero cell lines. Cell viability of the studied cell lines treated with CME, CEE and CME was shown in Figure 1. When CEE was used to treat these cell lines, there were statistically significant of \%cell viability between Vero cell and oral cancer cell lines ( $\mathrm{p}=0.03$ for ORL-48 and $\mathrm{p}=0.02$ for ORL-136).

\section{Discussion}

Northeast Thai vegetables have potential in prevention of chronic diseases including cardiovascular diseases (Kukongviriyapan et al., 2007) and cancer (Nonpunya et al., 2014). Thai medicinal plants such as Gloriosa superba 


\section{Bundit Promraksa et al}

L. (Colchinaceae) and Albizia chinensis (Osbeck) Merr. were reported to have in vitro anti-oral cancer potential (Manosroi A et al., 2015). Antioxidant activity of the vegetables is one factor involving in prevention/treatment of these diseases. It was reported that the ethanolic extract of Teaw leave, which contained chlorogenic acid, had high antioxidant activity (Maisuthisakul et al., 2007). In the present study, CME had the highest antioxidant activity which related to their phenolic and flavonoid contents (Table 1). The correlation between TPC and FRAP ( $\mathrm{r}=0.98)$, TPC and DPPH radical scavenging of the extracts $(r=0.92)$ were agreed with previous studies (Ramkissoon et al., 2013; Sebai, 2013). TFC also had correlation with both FRAP and DPPH assays ( $\mathrm{r}=0.92)$.

More than $90 \%$ of oral cancer is squamous cell carcinoma (Pathak et al., 2014). ORL-48 and ORL-136 cell lines were established from oral squamous cell carcinoma of Asian subjects (Hamid et al., 2007). Both of them were non HPV infection. Characterization of ORL-48 showed the overexpression of MDM2 which is a negative regulator of tumor suppressor gene (p53), whereas overexpressed EGFR, involve in cell proliferation and inhibit of apoptosis, were observed in ORL-136 cells (Hamid et al., 2007; Zanaruddin et al., 2013). A previous study reported that Brucea spp. had strong cytotoxic effect on ORL-48 cell line (Majid et al., 2014). In the present study, CME had IC50 value for ORL-48 (209.20 $\pm 8.14 \mu \mathrm{g}$ dry wt/mL) higher than ORL-136 (44.82 $\pm 27.95 \mu \mathrm{g}$ dry wt/ $\mathrm{mL}$ ) (Table 2). However, cytotoxicity of CME on Vero cell line is a limitation of using this extract as anticancer agent. Cytotoxicity of CEE on oral cancer cells, but not on normal Vero cells, indicated that CEE is a candidate source of anti oral cancer agents. Most phenolics play role as anticancer agents (Domenico et al., 2012). Potential anticancer activities of Teaw on MCF-7 (Woraratphoka et al, 2012) and HepG2 cells (Nonpunya et al., 2014) were reported. Teaw could inhibit HepG2 cell lines by activation of p53 protein, down-regulation of $\mathrm{NF}-x \mathrm{~B}$ and cyclin $\mathrm{D} 1$ proteins and activation of caspase cascade pathway (Waiyaput et al., 2012; Issara-Amphorn and T-Thienprasert, 2014; Nonpunya et al., 2014). The phenolics compound in Teawdang extracts might induce apoptosis in ORL-136 through p53-dependent and p53 independent (Kang and Jang., 2012). However, the lower expression of p53 in ORL-48 might lead to activation of the other proteins at late stage of apoptosis. From our previous report, CEE and CME had cytotoxic effect on both HPV-infected (HeLa and SiHa) and HPV-non infected (C-33A) cervical cancer cell lines. CEE contained gallic acid, resveratrol and quercetin (Promraksa et al., 2015). Gallic acid and quercetin can inhibit migration and invasion of oral squamous cell carcinoma, SCC-4 and SAS, through inhibition of NF- $x$ B and matrix metalloproteinase- 2 and -9 (Lai et al., 2013; Kuo et al., 2014). Resveratrol was reported to suppress cell growth and KB human oral cancer cells (Kim et al., 2011). Further purification and of active compounds from CEE and elucidating of their anticancer mechanism should be done to develop a novel anti oral cancer agents.

\section{Acknowledgements}

This work was supported by a research grant from Faculty of Medicine, Khon Kaen University (grant number I57208). The authors earnestly grateful to Prof. Aroonrat Chaveerach, Department of Biology, Faculty of Science, Khon Kaen University for taxonomial identification of the studied vegetable. We appreciated Prof. Sok Ching Cheong for the oral cell lines used in this study. We would like to thank staff of Research group of chronic inflammatory oral diseases and systemic diseases associated with oral health, Khon Kaen University, for providing facilities in cytotoxicity test.

\section{References}

Benzie IF, Strain JJ (1996). The ferric reducing ability of plasma (FRAP) as a measure of "antioxidant power": the FRAP assay. Anal Biochem, 239, 70-6.

Chen M, Rao Y, Zheng Y, et al (2014). Association between soy isoflavone intake and breast cancer risk for pre- and postmenopausal women: a meta-analysis of epidemiological studies. PLoS One, 9, 89288.

Clarke G, Ting K, Wiart C, et al (2013). High correlation of 2,2-diphenyl-1-picrylhydrazyl (DPPH) radical scavenging, ferric reducing activity potential and total phenolics content indicates redundancy in use of all three assays to screen for antioxidant activity of extracts of plants from the malaysian rainforest. Antioxidants, 2, 1-10.

Daduang J, Vichitphan S, Daduang S, et al (2011). High phenolics and antioxidants of some tropical vegetables related to antibacterial and anticancer activities. Afr J Pharm Pharmacol, 5, 608-15.

Di Domenico F, Foppoli C, Coccia R, et al (2012). Antioxidants in cervical cancer: chemopreventive and chemotherapeutic effects of polyphenols. Biochim Biophys Acta, 1822, 737-47.

Dzagnidze A, Katsarava Z, Makhalova J, et al (2007). Repair capacity for platinum-DNA adducts determines the severity of cisplatin-induced peripheral neuropathy. J Neurosci, 27, 9451-7.

Ferlay J, Soerjomataram I, Ervik M, et al (2013). GLOBOCAN 2012 v1.0, Cancer Incidence and Mortality Worldwide: IARC Cancer Base No. 11 (Internet). Lyon, France: International Agency for Research on Cancer; Available from: http://globocan.iarc.fr.

Gillison ML, D'Souza G, Westra W, et al (2008). Distinct risk factor profiles for human papillomavirus type 16-positive and human papillomavirus type 16-negative head and neck cancers. J Natl Cancer Inst, 100, 407-20.

Hamid S, Lim KP, Zain RB, et al (2007). Establishment and characterization of Asian oral cancer cell lines as in vitro models to study a disease prevalent in Asia. Int J Mol Med, 19, 453-60.

Heck JE, Berthiller J, Vaccarella S, et al (2010). Sexual behaviours and the risk of head and neck cancers: a pooled analysis in the International Head and Neck Cancer Epidemiology (INHANCE) consortium. Int J Epidemiol, 39, 166-81.

Issara-Amphorn J, T-Thienprasert NP (2014). Preliminary in vitro pro-apoptotic effects of Cratoxylum formosum crude leaf extracts. Int J Appl Res Nat Prod, 7, 26-30.

Jiang Y, Kusama K, Satoh K, et al (2000). Induction of cytotoxicity by chlorogenic acid in human oral tumor cell lines. Phytomedicine, 7, 483-91.

Kang HJ, Jang YJ (2012). Selective apoptotic effect of Zelkova 
serrata twig extract on mouth epidermoid carcinoma through p53 activation. Int J Oral Sci, 4, 78-84.

Khuhaprema T, Srivatanakul P, Sriplung H, et al (2010). Cancer in Thailand (2001-2003). National Cancer Institute Department of Med Services Ministry of Public Hlth, 5, 11-5.

Kim SH, Kim HJ, Lee MH, et al (2011). Resveratrol induces apoptosis of KB human oral cancer cells. J Korean Soc Appl $B l, \mathbf{5 4}, 966-71$.

Kukongviriyapan U, Luangaram S, Leekhaosoong K, et al (2007). Antioxidant and vascular protective activities of Cratoxylum formosum, Syzygium gratum and Limnophila aromatica. Biol Pharm Bull, 30, 661-6.

Kuo CL, Lai KC, Ma YS, et al (2014). Gallic acid inhibits migration and invasion of SCC-4 human oral cancer cells through actions of NF- $x \mathrm{~B}$, Ras and matrix metalloproteinase-2 and -9. Oncol Rep, 32, 355-61.

Lai WW, Hsu SC, Chueh FS, et al (2013). Quercetin inhibits migration and invasion of SAS human oral cancer cells through inhibition of NF- $x \mathrm{~B}$ and matrix metalloproteinase-2/-9 signaling pathways. Anticancer Res, 33, 1941-50.

Mahavorasirikul W, Viyanant V, Chaijaroenkul W, et al (2010). Cytotoxic activity of Thai medicinal plants against human cholangiocarcinoma, laryngeal and hepatocarcinoma cells in vitro. BMC Complement Altern Med, 10, 55.

Manosroi A, Akazawa H, Pattamapun K, et al (2015). Potent anti-proliferative effects against oral and cervical cancers of Thai medicinal plants selected from the Thai/Lanna medicinal plant recipe database "MANOSROI III". Pharm Biol, 53, 1075-81

Maisuthisakul P, Pongsawatmanit R, Gordon MH (2006). Antioxidant properties of Teaw ( Cratoxylum formosum Dyer) extract in soybean oil and emulsions. J Agric Food Chem, 54, 2719-25.

Maisuthisakul P, Pongsawatmanit R, Gordon MH (2007). Characterization of the phytochemicals and antioxidant properties of extracts from Teaw (Cratoxylum formosum Dyer). Food Chem, 100, 1620-9.

Majid MZ,Zaini ZM,Razak FA (2014). Apoptosis-Inducing effect of three medicinal plants on oral cancer cells KB and ORL-48. Sci World J, 2014, 125353

$\mathrm{Ng}$ IO, Lam KY, Ng M, et al (1998). Expression of P-glycoprotein, a multidrug-resistance gene product, is induced by radiotherapy in patients with oral squamous cell carcinoma. Cancer, 83, 851-7.

Nonpunya A, Weerapreeyakul N, Barusrux S (2014). Cratoxylum formosum (Jack) Dyer ssp. pruniflorum (Kurz) Gogel. (Hong ya mu) extract induces apoptosis in human hepatocellular carcinoma HepG2 cells through caspase-dependent pathways. Chin Med, 9, 12 .

Palasap A, Limpaiboon T, Boonsiri P, et al (2014). Cytotoxic effects of phytophenolics from Caesalpinia mimosoides Lamk on cervical carcinoma cell lines through an apoptotic pathway. Asian Pac J Cancer Prev, 15, 449-54.

Patel A, Patel A, Patel A, et al (2010). Determination of polyphenols and free radical scavenging activity of Tephrosia purpurea linn leaves (Leguminosae). Pharmacognosy Res, 2, 152-8.

Patel BP, Rawal UM, Rawal RM, et al (2008). Tobacco, antioxidant enzymes, oxidative stress, and genetic susceptibility in oral cancer. Am J Clin Oncol, 31, 454-9.

Pathak J, Swain N, Patel S, et al (2014). Histopathological variants of oral squamous cell carcinoma-institutional case reports. J Oral Maxillofac Pathol, 18, 143-5.

Perez-Sayans M, Somoza-Martin JM, Barros-Angueira F, et al (2010). Multidrug resistance in oral squamous cell carcinoma: The role of vacuolar ATPases. Cancer Lett,
295, 135-43.

Promraksa B, Daduang J, Khampitak T, et al (2015). Anticancer potential of Cratoxylum formosum subsp. pruniflorum (Kurz.) Gogel. extracts against cervical cancer cell lines. Asian Pac J Cancer Prev. (In press)

Ramkissoon JS, Mahomoodally MF, Ahmed N, et al (2013). Antioxidant and anti-glycation activities correlates with phenolic composition of tropical medicinal herbs. Asian Pac J Trop Med, 6, 561-9.

Sebai H, Souli A, Chehimi L, et al (2013). In vitro and in vivo antioxidant properties of Tunisian carob (Ceratonia siliqua L.). J Med Plants Res, 7, 85-90.

Sturgis EM, Wei Q, Spitz MR (2004). Descriptive epidemiology and risk factors for head and neck cancer. Semin Oncol, 31, 726-33.

Surh YJ (2003). Cancer chemoprevention with dietary phytochemicals. Nat Rev Cancer, 3, 768-80.

Vatanasapt P, Suwanrungruang K, Kamsa-Ard S, et al (2011). Epidemiology of oral and pharyngeal cancers in Khon Kaen, Thailand: a high incidence in females. Asian Pac J Cancer Prev, 12, 2505-8.

Waiyaput W, Payungporn S, Issara-Amphorn J, et al (2012). Inhibitory effects of crude extracts from some edible Thai plants against replication of hepatitis B virus and human liver cancer cells. BMC Complement Altern Med, 12, 246

Wang X, Ouyang Y, Liu J, et al (2014). Fruit and vegetable consumption and mortality from all causes, cardiovascular disease, and cancer: systematic review and dose-response meta-analysis of prospective cohort studies. BMJ, 349, 4490 .

Woraratphoka J, Intarapichet K, Indrapichate K (2012). Antioxidant activity and cytotoxicity of six selected, regional, Thai vegetables. Am-Euras J Toxicol Sci, 4, 108-17.

Xiong J, Liu XH, Bui VB, et al (2014). Phenolic constituents from the leaves of Cratoxylum formosum ssp. pruniflorum. Fitoterapia, 94, 114-9.

Zanaruddin SN, Yee PS, Hor SY, et al (2013). Common oncogenic mutations are infrequent in oral squamous cell carcinoma of Asian origin. PLoS One, 8, 80229. 